University of Pennsylvania Carey Law School

Penn Law: Legal Scholarship Repository

Faculty Scholarship at Penn Law

1969

\title{
The Court Acknowledges the Illegitimate: Levy v. Louisiana and Glona v. American Guarantee \& Liability Insurance Co.
}

John C. Gray Jr.

David Rudovsky

University of Pennsylvania Carey Law School

Follow this and additional works at: https://scholarship.law.upenn.edu/faculty_scholarship

Part of the Civil Rights and Discrimination Commons, Constitutional Law Commons, Family Law Commons, Fourteenth Amendment Commons, Jurisprudence Commons, and the Law and Society Commons

\section{Repository Citation}

Gray, John C. Jr. and Rudovsky, David, "The Court Acknowledges the Illegitimate: Levy v. Louisiana and Glona v. American Guarantee \& Liability Insurance Co." (1969). Faculty Scholarship at Penn Law. 1506. https://scholarship.law.upenn.edu/faculty_scholarship/1506

This Article is brought to you for free and open access by Penn Law: Legal Scholarship Repository. It has been accepted for inclusion in Faculty Scholarship at Penn Law by an authorized administrator of Penn Law: Legal Scholarship Repository. For more information, please contact PennlawIR@law.upenn.edu. 


\title{
University of Pennsylvania Law Review
}

\author{
FOUNDED 1852
}

Formerly

American Law Register

\section{THE COURT ACKNOWLEDGES THE ILLEGITIMATE :} LEVY v. LOUISIANA AND GLONA v. AMERICAN
GUARANTEE \& LIABILITY INSURANCE CO.

\section{JoHN C. Gray, JR.† AND Davm RudotsKy $\nmid \dagger$}

Discriminations based on illegitimacy pervade American law..$^{1}$ Deriving from a long tradition of prejudice, ${ }^{2}$ they adversely affect a large and growing class of persons. ${ }^{3}$ Nevertheless, until the recent decisions of the United States Supreme Court in Levy v. Louisiana ${ }^{4}$ and Glona v. American Guaranty \& Liability Insurance Co., ${ }^{5}$ invalidating a Louisiana statute which denied recovery for wrongful death to illegiti-

$\dagger$ A.B. 1964, LL.B. 1967, Harvard University. Member, Massachusetts and New York Bars. Presently associated with Community Action for Legal Services (CALS).

i B.A. 1964, Queens College; LL.B. 1967, New York University. Member, New York Bar. Presently a Graduate Fellow in the Community Law and Criminal Litigation Program at the University of Pennsylvania School of Law.

The authors acknowledge with gratitude the suggestions and assistance of Norman Dorsen, Professor of Law and Director of the Arthur Garfield Hays Civil Liberties Program at New York University School of Law.

Messrs. Gray and Rudovsky participated in the preparation of the brief for appellants in the Levy case.

1 The nature of these discriminations is discussed at length in part II infra. They are in effect in most states. Only Arizona and Oregon have substantially eliminated legal discrimination against illegitimates. ARTz. REV. STAT. ANN. \$14-206 (1956); ORE. Rev. Stat. \$ 109.060 (1963). See Krause, Bringing the Bastard into the Great Society-A Proposed Uniform Act on Legitimacy, 44 TEx. I. REv. 829, 845 (1966).

2 See, e.g., Fodor, Emotional Trauma Resulting from Illegitimate Birth, 54 Archives of NeUrology AND Psychiatry 381 (1945); Jenkins, An Experimental Study of the Relationship of Legitimate and Illegitimate Birth to School and Personal and Social Adjustment of Negro Children, 64 AM. J. Sociology 169 (1958).

3 In 1950, the rate of illegitimacy in the United States was approximately one out of every 25 births. By 1960 , the ratio had become one out of 19 , and by 1964 , one in 15 , or about 275,000 out of about 4 million live births. U.S. BUREAU OF THE CENSUS, Statistical AbStract of the United States, $47-49$ (1966). See also Foster \& Freed, Unequal Protection: Poverty and Family Law, 42 IND. L.J. 192, 220 (1967).

* 391 U.S. 68 (1968)

6 391 U.S. 73 (1968). 
mate children and their parents, discrimination based on status of birth largely escaped constitutional review. ${ }^{6}$ This is particularly surprising during a period in which courts have invalidated with increasing frequency classifications predicated on race, ${ }^{7}$ ancestry, ${ }^{8}$ and economic status. ${ }^{9}$

The decisions in Levy and Glona require a reexamination of the constitutional limitations on discrimination against illegitimates. The holdings left important questions unanswered, unnecessarily clouding the implications of these decisions for remaining discriminations against illegitimates. We conclude, however, that Levy and Glona provide a basis from which all the major legal disadvantages suffered by reason of illegitimacy can be challenged successfully. ${ }^{10}$

\section{Levy AND Glona}

Levy $v$. Louisiana arose in a context which well illustrates the typical effect of discrimination against illegitimates. Louise Levy, a black woman, came to the Charity Hospital in New Orleans with symptoms of tiredness, dizziness, chest pain, and slowness of breath. The doctor to whom she was assigned purportedly examined her, but he failed to take her blood pressure or conduct any other test which would have revealed that she suffered from hypertensive uremia. The doctor sent her home with tonic and tranquilizers. When she returned a week later with more severe symptoms, he merely looked at her, told her she was not taking the prescribed medicine and recommended a psychiatrist. Ten days later she died. ${ }^{11}$

Pursuant to the Louisiana wrongful death statute, ${ }^{12}$ an action was brought on behalf of her five children-all illegitimate-for damages

6 The legal issues involved have only recently received any serious attention. The leading article in the field is Krause, Equal Protection for the Illegitimate, 65 MICE. L. REv. 477 (1967). See also Foster \& Freed, Unequal Protection: Poverty and Family Law, 42 IND. L.J. 192 (1967); Krause, Bringing the Bastard into the Great Society-A Proposed Uniform Act on Illegitinacy, 44 TEx. L. REv. 829 (1966); Dorsen \& Rudovsky, Equality for the Illegitimate?, 8 WELFARE L. BuLL. 13 (1967).

7 See generally T. Emerson, D. Haber \& N. Dorsen, 2 Politrcal and CiviL Rights IN THE UNITED STAtes (1967).

8 E.g., Oyama v. California, 332 U.S. 633 (1948).

๑ E.g., Harper v. Virginia Bd. of Elections, 383 U.S. 663 (1966); Douglass v.

California, 372 U.S. 353 (1963) ; Griffin v. Illinois, 351 U.S. 12 (1955).

10 In the wake of Levy and Glona several remaining discriminations have already fallen. See, e.g., Michaelson v. Undhjem, 162 N.W.2d 861 (N.D. 1968); In re Cager, 251 Md. 473, 248 A.2d 384 (1968); R. v. R., 431 S.W.2d 152 (Mo. Sup. Ct. 1968).

11 Brief for Appellant at 4-5, Levy v. Louisiana, 391 U.S. 68 (1968).

12 Article 2315 of the Louisiana Civil Code provides:

Every act whatever of man that causes damage to another obliges him by whose fault it happened to repair it.

The right to recover damages to property caused by an offense or quasi offense is a property right which, on the death of the obligee, is inherited by his legal, instituted, or irregular heirs, subject to the community rights of the surviving spouse. 
suffered by them for the loss of their mother and for damages based on the survival of a cause of action for pain and suffering possessed by their mother at her death. The suit was dismissed by the Louisiana district court. The court of appeals affirmed, holding that the denial to illegitimates of the right to recover was properly "based on morals and general welfare because it discourages bringing children into the world out of wedlock." 13 After the Supreme Court of Louisiana denied certiorari, ${ }^{14}$ the United States Supreme Court noted probable jurisdiction. ${ }^{15}$

In Glona, a Texas domiciliary brought a diversity action in a federal district court in Texas for the wrongful death of her illegitimate son in an automobile accident in Louisiana. The court dismissed the suit, holding that under Louisiana law the mother had no right of action for the death of her illegitimate child. The court of appeals affirmed, rejecting the assertion that this construction violated the equal protection clause. ${ }^{16}$ The Supreme Court granted the petition for certiorari. ${ }^{17}$

Writing for a majority of six in each case, Justice Douglas held that the Louisiana wrongful death statute denied equal protection of the law to both illegitimate children and parents. Read in their broadest sense, the opinions condemn generally classifications based on illegitimacy. But Justice Douglas did not clearly specify the grounds for decision and left undiscussed several possible arguments.

In Levy, Justice Douglas began by articulating the general principle of equal protection:

While a State has broad power when it comes to making classifications (Ferguson v. Skrupa, 372 U.S. 726, 732), it

The right to recover all other damages caused by an offense or quasi offense, if the injured person dies, shall survive for a period of one year from the death of deceased in favor of: (1) the surviving spouse and child or children of the deceased, or either such spouse or such child or children; (2) the surviving father and mother of the deceased, or either of them, if he left no spouse or child surviving; and (3) the surviving brothers and sisters of the deceased, or any of them, if he left no spouse, child, or parent surviving. The survivors in whose favor this right of action survives may also recover the damages which they sustained through the wrongful death of the deceased. A right to recover damages under the provisions of this paragraph is a property right which, on the death of the survivor in whose favor the right of action survived, is inherited by his legal, instituted, or irregular heirs, whether suit has been instituted thereon by the survivor or not.

As used in this article, the words "child," "brother," "sister," "father," and "mother" include a child, brother, sister, father, and mother, by adoption, respectively.

LA. Crv. Cone ANN. art. 2315 (West Supp. 1969).

13192 So. 2d 193, 195 (La. App. 1966).

14250 La. 25, 193 So. 2d 530 (1966).

15389 U.S. 925 (1967).

16379 F.2d 545 (5th Cir, 1967).

17389 U.S. 969 (1967). 
may not draw a line which constitutes an invidious discrimination against a particular class. See Skinner v. Oklahoma, 316 U.S. 535, 541-542. Though the test has been variously stated, the end result is whether the line drawn is a rational one. See Morey v. Doud, 354 U.S. 457, 465-466. ${ }^{18}$

Next, Justice Douglas faced the issue of what standard should be applied to determine the validity of the classifications:

In applying the Equal Protection Clause to social and economic legislation, we give great latitude to the legislature in making classifications. Williamson v. Lee Optical Co., 348 U.S. 483, 489; Morey v. Doud, supra, at 465-466. . . . However . . . we have been extremely sensitive when it comes to basic civil rights (Skinner v. Oklahoma, supra, at 541; Harper v. Board of Elections, 383 U.S. 663, 669-670) and have not hesitated to strike down an invidious classification even though it had history and tradition on its side. (Brown v. Board of Education, 347 U.S. 483; Harper v. Board of Elections, supra, at 669.) ${ }^{19}$

When Justice Douglas's opinion is read together with the dissent by Justice Harlan, the reader's first impression is that the issue narrows to a discussion of whether the Louisiana statute is unconstitutional under the traditional standard applied to economic statutes: does the classification bear a rational relation to the purposes of the statute? But Justice Douglas provides the tools for different analyses, for, as the excerpt quoted immediately above indicates, the Supreme Court has long viewed with suspicion two types of statutes: (1) those which encroach on basic civil rights and (2) those which establish classifications based on race or ancestry. Under the first category, special protection has been afforded to a wide range of conduct including the right to vote, ${ }^{20}$ the right to marry ${ }^{21}$ and to have offspring, ${ }^{22}$ and various rights protected by the first amendment. ${ }^{23}$ Justice Douglas apparently reasoned that the right to wrongful death recovery, at least in the context of Levy, was also a basic civil right: "[ $t]$ he rights asserted here involve the intimate, familial relationship between a child and his own mother." 24

On this basis, he applied the test of stringent constitutional scrutiny and, as discussed below, ${ }^{25}$ invalidated the Louisiana classifica-

18391 U.S. at 71.

19 Id.

20 See, e.g., Harper v. Virginia Bd. of Elections, 383 U.S. 663 (1966).

21 Loving v. Virginia, 388 U.S. 1 (1967).

22 Skinner v. Oklahoma, 316 U.S. 535 (1942).

23 See, e.g., Dombrowski v. Pfister, 380 U.S. 479 (1965) ; New York Times Co. v. Sullivan, 376 U.S. 254 (1964); NAACP v. Button, 371 U.S. 415 (1963) ; Speisser v. Randall, 357 U.S. 513 (1958).

24391 U.S. at 71.

25 Text accompanying notes $42-45$ infra. 
tion. The Court's characterization of the rights involved is of no small significance. If the right to wrongful death recovery is to be considered "basic" in our constitutional scheme, other economic relationships which similarly can be said to involve "intimate, familial relationships" would also seem to be deserving of special constitutional protections. Although legislative judgments in the area of economic regulation have been virtually immune from constitutional challenge under the fourteenth amendment since the thirties, ${ }^{26}$ some courts have recently indicated that legislative or administrative restrictions on "economic" rights are not to be treated as mere economic regulation cases if they affect social or political relationships, particularly in the area of public assistance. ${ }^{27}$ Lewy may be read to support the emergence of preferred social and economic rights, ${ }^{28}$ among which may be a right to receive welfare benefits or comparable assistance. ${ }^{29}$

To require close constitutional scrutiny in Levy, however, it is not necessary to argue that wrongful death recovery is entitled to the protections afforded "basic civil rights." What makes this particular statute suspect in its own right is that illegitimate status of birth is the basis of the classification which is used to determine to whom the right will be granted. The Supreme Court has ruled in several contexts that classifications based on race or ancestry are "constitutionally suspect" 30 and may only be used if there "clearly appears . . . some overriding statutory purpose." 31 While it can be argued that the fourteenth amendment applies with unique force to racial discrimination, ${ }^{32}$ the Supreme Court has long invoked equal protection principles to protect other minority groups from arbitrary governmental action, ${ }^{33}$ and discriminations based on status of birth are closely analogous to those predicated on race and ancestry.

${ }^{26}$ See, e.g., Williamson v. Lee Optical, Inc., 348 U.S. 483 (1955); Day-Brite Lighting, Inc. v. Missouri, 342 U.S. 421 (1952).

27 See, e.g., King v. Smith, 277 F. Supp. 31 (M.D. Ala.), aff'd on other gronnds; Smith v. King, 392 U.S. 309 (1968) ; cf. Shapiro v. Thompson, 394 U.S. 618 (1969); Williams v. Dandridge, 297 F. Supp. 450 (D. Md. 1969), appeal docketed, 38 U.S.L.W. 3003 (July 1, 1969) (No. 1410, 1968 term; renumbered No. 131, 1969 term); Westbury v. Fisher, 297 F. Supp. 1109 (S.D. Me. 1969).

28 See Henkin, Forward, The Supreme Court 1967 Term, 82 HaRv. L. Rev. 63, 91-92, n.92 (1968).

29 See Shapiro v. Thompson, 394 U.S. 618 (1969) ; Rothstein v. Wyman, 69 Civ. 2763 (S.D.N.Y., August 4, 1969).

30 Harper v. Virginia Bd. of Elections, 383 U.S. 663 (1966); McLaughlin v. Florida, 379 U.S. 184 (1964); Korematsu v. United States, 323 U.S. 214 (1944).

31 McLaughlin v. Florida, 379 U.S. 184, 192 (1964).

32 See, e.g., Strauder v. West Virginia, 100 U.S. 303 (1880); Slaughter-House Cases, 83 U.S. (16 Wall.) 36 (1873); Kinoy, The Constitutional Right of Negro Freedom, 21 RUTGERS L. REV. 387 (1967).

33 See, e.g., Carrington v. Rash, 380 U.S. 89 (1965) ; Griffin v. Illinois, 351 U.S. 12 (1956); Hernandez v. Texas, 347 U.S. 475 (1954); Takahashi v. Fish \& Game Comm'n, 334 U.S. 410 (1948); Oyama v. California, 332 U.S. 633 (1948). 
Such discriminations are imposed without regard to an individual's actions or capacities and affect persons who have no more control over their birth status than the black man has over the color of his skin. Consider, for example, Oyama v. California, ${ }^{34}$ in which the Supreme Court struck down a provision in California's Alien Land Law which created a prima facie presumption that title to land conveyed to the child of an "ineligible alien" (that is, a Japanese citizen), but paid for by the alien, was held for the benefit of the alien and would escheat to the state. The Court assumed that the underlying purpose of the Alien Land Law, preventing ineligible aliens from owning certain types of land, was constitutional, but ruled nevertheless that the section disadvantaging children of the alien violated the equal protection clause. ${ }^{35}$ The import of Oyama is clear. Even if the status of a parent can justify discrimination against him, it cannot justify discrimination against his child. Discrimination against an illegitimate child because of the marital status of his parents is in this sense clearly based on ancestry.

Classifications based on status of birth are also similar to racial classifications in that illegitimate share with nonwhite Americans a history of widespread private discrimination reinforced and institutionalized by legal disabilities. They too are second class citizens in a society in which illegitimacy has been described as a "psychic catastrophe." 36 Illegitimates suffer from psychological and social handicaps closely comparable to those which result from racial discrimination. ${ }^{37}$ In this context it is not surprising that legal discrimination against illegitimates tends to fall most harshly on blacks and the poor, ${ }^{38}$ and that in some instances this discrimination may have been designed with this specific end in mind. ${ }^{39}$

\footnotetext{
34332 U.S. 633 (1948).

$35 I d$. at 640.

36 Fodor, supra note 2.

37 See Jenkins, supra note 2.

38
}

Nationally, in 1963, the Vital Statistics Division of the Public Health Service, U.S. Department of Health, Education and Welfare, estimated that the white illegitimacy rate was 30.7 per 1,000 live births; the non-white rate was 235.9. . . . See United States Department of Labor, Office of Policy Planning and Research, the Negro Family, The Case for National Action (The Moynihan Report), 8-9, 59. By 1965, the white rate was 39.6 and the Negro rate was 263.2 per thousand live births. U.S. NEWS AND WORLD REPORT, Oct. 2,1967 at 84.

Brief for NAACP Legal Defense Fund as Amicus Curiae at 18 n.17, Levy v. Louisiana, 391 U.S. 68 (1968).

39 In 1960 as part of a large anti-integration package passed at an emergency session of the legislature, Louisiana instituted new measures to penalize illegitimate children and their parents. N.Y. Times, Aug. 28, 1960, at 62, col. 4. "Conceiving and giving birth to two or more illegitimate children" was declared to be a crime for both father and mother. LA. REV. STAT. ANN. \$14:79.2 (1969). 
Finally, like nonwhites, illegitimates constitute a class that is a "discrete and insular" minority peculiarly susceptible to prejudice which tends to "curtail the operation of those political processes ordinarily to be relied upon to protect minorities . . . ." 40 Indeed, the stigma of "bastardy" in American society is so strong ${ }^{41}$ that illegitimates may be even more disabled than nonwhites from forming a political force to effect changes on a social or legislative level.

Without expressly resolving the question whether the Louisiana wrongful death statute was constitutionally suspect and, if so, for what reason, Justice Douglas concluded,

Legitimacy or illegitimacy of birth has no relation to the nature of the wrong allegedly inflicted on the mother. These children, though illegitimate, were dependent on her; she cared for them and nurtured them; they were indeed hers in the biological and in the spiritual sense; in her death they suffered wrong in the sense that any dependent would.

We conclude that it is invidious to discriminate against them when no action, conduct, or demeanor of theirs is possibly relevant to the harm that was done the mother. ${ }^{42}$

This holding is unclear in several respects. First, Justice Douglas never explicitly stated which constitutional standard he was applying. If, as he implied, the classification bears no rational relation to the purposes of the Louisiana wrongful death act, the statute is unconstitutional even under the traditional economic standard. The minimum test under the equal protection clause, of course, is whether this rational relationship exists. ${ }^{43}$ It seems beyond contradiction that the purposes of the statute-" to save [children] harmless during their minority from the loss of benefits (material and moral) which they would have received had their [parent] lived up to the time of their respective

Another statute provided that categorical assistance under the Social Security Act could not be given to a family if the mother had an illegitimate child after receiving assistance. LA. REv. STAT. ANN. \$ 46:233 (1969). Under this "suitable home" plan, 0,000 families with 22,500 children were removed from public welfare. Ninety-five per cent of those affected were Negroes, although two-thirds of the welfare caseload a few months earlier were Negroes. W. BeLl, Amo to Dependent CHIIDREN, 183 (1965). This requirement was prohibited in a major statement by the Department of Health, Education and Welfare. U.S. Bureau of Public Assistance, State Letter No. 454, Jan. 17, 1961.

40 United States v. Carolene Prod. Co., 304 U.S. 144, 152-53 n.4 (1938). The Court in Carolene suggested the possibility that minorities are subject to such prejudice without reaching the conclusion that in fact they are. See also Hobson v. Hansen, 269 F. Supp. 401, 507-08 (D.D.C. 1967), aff'd, 408 F.2d 175 (D.C. Cir. 1969), in which Judge J. Skelly Wright speaks in language indicating that he has assumed this conclusion.

41 See sources cited note 2 supra.

42391 U.S. at 72 (footnotes omitted).

43 Morey v. Doud, 354 U.S. 457, 465-66 (1957). 
majorities" 44 and to hold tortfeasors responsible for their actionsapply equally to illegitimate and legitimate children. ${ }^{45}$

Louisiana, however, asserted as a justification for its statute the collateral policy of deterring out-of-wedlock births. This argument, rejected by the Court without discussion, might have been disposed of on any of three grounds. First, the justification is offensive to common sense. It would be truly remarkable if persons contemplating behavior which might produce a child out-of-wedlock were deterred by the possibility that the child would not be able to recover for their wrongful death. Perhaps Justice Douglas considered this point too obvious to state. In Glona, where the deterrence policy had a stronger foundation because the discrimination was aimed at the "wrongdoing parent," he dismissed it as "farfetched." 46

Second, even assuming that the discrimination constituted a reasonably effective deterrent, a difficult question of equal protection theory is raised: can a classification which is not rationally related to the purposes of the statutory scheme be justified by its promotion of an unrelated state interest? In Levy, the deterrence policy conflicted directly with the purposes of the wrongful death statute: protecting dependents and holding tortfeasors responsible for their actions. Justice Douglas did not advert to the question whether the collateral nature of the deterrence justification was relevant to the rationality of the statute since he probably rejected the deterrence theory as factually unfounded. But his ambiguous language leaves open the argument that a collateral policy cannot justify a classification under the strict test of equal protection. ${ }^{47}$

A third ground for rejecting the deterrence theory is due process. Two substantive due process theories were urged upon the Court in

44 Eichorn v. New Orleans \& C.R. Light \& Power Co., 114 La. 712, 724, 38 So. 526,530 (1905). Iouisiana's wrongful death act, like that of most states, was an "adoption" of the first wrongful death act in England, Lord Campbell's Act, 9 \& 10 Vict. c. 93 (1846). Cooper v. Blanck, 39 So. 2d 352, 359 (La. App. 1923). See generally, S. SPEISER, RECOVERY FOR WRONGFul DEATH (1966).

45 See Middleton v. Luckenbach S.S. Co., 70 F.2d 326, 330 (2d Cir. 1934):

The purpose and object of the [federal death] statute is to continue the support of dependents after a casualty. To hold that these [illegitimate] children or the parents do not come within the terms of the act would be to defeat the purposes of the act. The benefit conferred beyond being for such beneficiaries is for society's welfare in making provision for the support of those who might otherwise become dependent.

Interestingly, the dissent in Glona reached a similar conclusion, 391 U.S. at 80, but still found no constitutional infirmity in the Louisiana act.

46391 U.S. at 75. It is, however, possible that knowledge of a wide pattern of discrimination against illegitimates might have some deterrent effect.

47 See, e.g., Ratner, Inter-Neighborhood Denials of Equal Protection in the Provision of Municipal Services, 4 HARv. CIV. RIGHTS-Crv. LIB. L. REv. 1, 15-18 (1968); Note, Student Deferment and Equal Protection, 1 Colum. SuRvey of HuMaN RrGHrs L., 68, 77-79 (1968); cf. Harper v. Virginia Bd. of Elections, 383 U.S. 663 (1966); Reynolds v. Sims, 377 U.S. 533 (1964); Griffin v. Illinois, 351 U.S. 12 (1956). 
Levy. ${ }^{4}$ One was the requirement, similar to that of equal protection, that the laws serve a rational purpose. ${ }^{49}$ The other was the principle which precludes a state from denying persons rights on the basis of a condition over which they have no control. In the leading case for the latter theory, Robinson v. California, ${ }^{50}$ the Court ruled that the "status" of narcotics addiction was an "illness which may be contracted innocently or involuntarily" and, therefore, punishment for the condition was "cruel and unusual" under the eighth and fourteenth amendments. ${ }^{51}$ Other courts have applied the "status" principle to invalidate laws penalizing vagrancy. ${ }^{52}$ In a more recent case, Powell v. Texas, ${ }^{53}$ the Court refused by a 5-4 margin to extend the Robinson rationale to benefit a chronic alcoholic convicted of public drunkenness. The decision in Powell, however, turned on a concurring opinion of Justice White, who, while declining to reverse the conviction on the particular facts, said: "Unless Robinson is to be abandoned, . . . . the chronic alcoholic with an irresistible urge to consume alcohol should not be punishable for drinking or for being drunk." 54 Thus, Powell can be read to stand for the proposition that it is unconstitutional to penalize criminally the status of "chronic alcoholism."

Since illegitimacy is a status which attaches to a person at birth as the result of conduct of other persons, due process should preclude the denial of rights otherwise available to him on that basis. ${ }^{55}$ Justice Douglas seemingly adverted to due process principles in his conclusion that "it is invidious to discriminate against [the Levy children] when no action, conduct, or demeanor of theirs is possibly relevant to the harm that was done the mother." 56 Whether or not this statement was intended to dispose of the deterrence argument on due process

48 Brief for Appellant at 19-21, Levy v. Louisiana, 391 U.S. 68 (1968).

49 Schware v. Board of Bar Examiners, 353 U.S. 232, 249 (1957) (Frankfurter, $J$., concurring). This is one of several areas where equal protection and due process principles "merge." See Labat v. Bennett, 365 F.2d 698, 723 (5th Cir. 1966). As the Supreme Court has stated: "[T] stemming from our American ideal of fairness, are not mutually exclusive." Bolling v. Sharpe, 347 U.S. 497, 499 (1954).

50 370 U.S. 660 (1962).

61 Id. at 667 .

52 See Fenster v. Leary, 20 N.Y. 2 d 309, 229 N.E.2d 426, 282 N.Y.S.2d 739 (1967); Smith v. Hill, 285 F. Supp. 556 (E.D.N.C. 1968); Baker v. Binder, 274 F. Supp. 658 (W.D. Ky. 1967); Alegata v. Massachusetts, 353 Mass. 287, 231 N.E.2d 201 (1967).

53392 U.S. 514 (1968).

54 Id. at $548-49$.

65 A leading legal philosopher, Professor Lon Fuller, maintains that a rule which an individual has no opportunity to obey is not a law at all, but an arbitrary application of governmental force. L. FULLER, THE MORALITY OF LAW, 39, 70-73 (1964). See also Oyama v. California, 332 U.S. 633 (1948).

The principle is also analogous to the constitutional prohibition against ex post facto laws.

56391 U.S. at 72 (footnotes omitted). 
grounds, the language suggests the viability of a due process approach in other cases. ${ }^{57}$

Further ambiguities in the Levy opinion derive from the Court's emphasis on the care and attention Louise Levy gave her children and its conclusion that "in her death they suffered wrong in the sense that any dependent would." 58 Probably as a result of this emphasis, upon remand the Supreme Court of Louisiana said in dictum that

[t] he United States Supreme Court has held that . . . when a parent openly and publicly recognizes and accepts an illegitimate to be his or her child and the child is dependent upon the parent, such an illegitimate is a "child" as expressed in Civil Code Article 2315.

Thus the Louisiana court would limit Levy to cases in which the illegitimate child has been informally acknowledged and is an actual dependent. However, neither of these limitations is constitutional. First, the Louisiana court would substitute a requirement of informal acknowledgement for its old requirement of formal acknowledgement. ${ }^{60}$ But to the child the new requirement is equally as objectionable as the old since he has no control over either kind of acknowledgement. ${ }^{01}$

Second, since the legitimate child does not need to prove actual dependency to recover, ${ }^{62}$ neither should the illegitimate one. While a state could limit recovery to those actually dependent on the deceased, ${ }^{63}$ status of birth cannot constitutionally be used as an indicator of dependency. Not only is there probably no empirical proof that illegitimate children are less often dependent on their mothers than legitimate children, but even if there were a demonstrable connection between legitimacy and dependency, the state could not use this suspect classification because it could achieve the objective of limiting recovery to dependents by requiring all claimants to prove dependency. The use of status of birth as an indirect method of identifying nondependents

$57 \mathrm{~A}$ due process approach is also suggested as a basis for the decision by the Court's rhetorical question: "Why should the illegitimate child be denied rights merely because of his birth out of wedlock?" Id. at 71 .

$58 I d$. at 72.

50 Levy v. Louisiana, 253 La. 73, 80, 216 So. $2 d$ 818, 820 (1968). On remand from the United States Supreme Court, the Iouisiana Supreme Court raised on its own motion the question whether the Court's decision had established a cause of action for the illegitimate children or whether it had invalidated the Louisiana wrongful death statute with respect to all recovery by children. The Louisiana court ultimately allowed the plaintiffs a cause of action. $253 \mathrm{La} .73,216$ So. 2d 818 (1968).

60 Under an 1870 Louisiana law, some children can be legitimated by notarial act. See LA. Civ. Code Ann. arts. 200-05, 208-09, 212 (West 1952).

01 Text accompanying notes 107-111 infra.

62 See LA. Civ. Code AnN. art. 2315 (West 1969).

63 See note 62 supra. The survivorship aspect of the Louisiana statute, discussed at text accompanying notes 81-88 infra, allows children to recover even if they suffered no damages personally. 
violates two closely related constitutional principles. It is unnecessary because a less drastic means of achieving the public purpose exists. It is also unnecessary because it is imprecise: many children, like the Levys, are dependent and some legitimate ones are not. Under most circumstances a state need not choose the most precise way to fulfill its purpose, merely one which has some rational tendency to do so. ${ }^{64}$ However, where basic civil rights or suspect classifications are involved, the principle is well established that the state must select the method of achieving its goal which least prejudices those within the protected group. ${ }^{\text {es }}$

The Court has relied on the requirements of necessity and precision as the basis of decision under several constitutional clauses to protect a number of substantive rights. It has identified two basic kinds of statutory imprecision: overinclusiveness and underinclusiveness. In the area of basic civil rights, overinclusiveness is seen, for example, in the doctrine of "overbreadth," which requires that when first amendment rights are threatened, even statutes seeking permissible goals must be narrowly drawn. ${ }^{68}$ The same principle applies when other fundamental rights are threatened. ${ }^{67}$ The Court dealt with a different type of statutory imprecision in Skinner $v$. Oklahoma ${ }^{68}$ where it struck down a classification on the ground, not that it was overbroad, but that it was underinclusive. An Oklahoma law allowed compulsory sterilization of certain habitual criminals. The proscribed crimes included common law larceny, but excluded embezzlement. While conceding that a state normally is given wide deference in its classifications and was not constrained from recognizing degrees of evil, the Court held that where fundamental rights were at stake, the state could not single out a particular group while excluding other groups whose position cannot be rationally differentiated. ${ }^{69}$

More recently, in Aptheker v. Secretary of State, ${ }^{70}$ the Court applied the concepts of both overinclusiveness and underinclusiveness to a statute that made it a crime for members of Communist organizations, which had been ordered to register under the Subversive Activities Control Act, to use or apply for passports for foreign travel. Identifying the purpose of the statute as the protection of national security, ${ }^{71}$ the Court held that the statute swept "too widely and too

64 E.g., Williamson v. Lee Optical Co., 348 U.S. 483 (1955).

65 See notes $20-23$ supra \& accompanying text.

66 See, e.g., Shelton v. Tucker, 364 U.S. 479 (1960) ; Cantwell v. Connecticut, 310 U.S. 296 (1940); Schneider v. Irvington, 308 U.S. 147 (1939) ; Lovell v. Griffin, 303 U.S. 444 (1938).

67 See, e.g., Griswold v. Connecticut, 381 U.S. 479 (1965).

68316 U.S. 535 (1942).

69 Id. at 542 .

70378 U.S. 500 (1964).

71 Id. at 509 . 
indiscriminately across the liberty" $\tau 2$ of travel protected by the fifth amendment :

The prohibition against travel is supported only by a tenuous relationship between the bare fact of organizational membership and the activity Congress sought to proscribe. The broad and enveloping prohibition indiscriminately excludes plainly relevant considerations such as the individual's knowledge, activity, commitment, and purposes in and places for travel. ${ }^{73}$

\section{For example,}

[I]f a notified member of a registered organization were to apply for a passport to visit a relative in Ireland, or to read rare manuscripts ... . [at] Oxford University [he] would be guilty of a crime; whereas, if he were to travel to Canada or Latin America to carry on criminal activities directed against the United States, he could do so free from the prohibitive reach of [the statute]. ${ }^{74}$

The Court relied on a similar theory in United States $v$. Brozmn. ${ }^{75}$ There it held that a statute making it a crime for a member of the Communist Party to serve as an officer of a labor union was an unconstitutional bill of attainder because it was both "too narrow in specifying the particular class . . . [and] too broad in treating all members of that class alike." 76

While the cases in which the requirements of necessity and precision were developed involved basic civil rights, the underlying principles have been carried over to attack racial and other suspect classifications. The Court applied the necessity standard most clearly to a suspect classification in McLaughlin v. Florida, ${ }^{\mathbf{7 7}}$ in which Florida argued that a statute outlawing interracial "cohabitation" was rationally related to its ban on mixed marriages. Assuming, arguendo, that the marriage bar was constitutional, the Court said,

Florida has offered no argument that the State's policy against interracial marriages cannot be as adequately served by the general, neutral, and existing ban on illicit behavior as by a provision ... which singles out the promiscuous interracial couple for statutory treatment. ${ }^{78}$

$72 I d$. at 514.

$73 \mathrm{Id}$.

74 Id. at 512 .

75381 U.S. 437 (1965).

$76 \mathrm{Id}$. at 464 (White, J., dissenting).

77379 U.S. 184 (1964).

78 Id. at 196. See also id. at 197 (Harlan, J., concurring). 
In McLaughlin, the Court did not rely on the imprecision of the challenged statute, but on the more general principle that the racial classification was unnecessary. The imprecise statute is an a fortiori case, however, since existence of the more precise way of achieving a goal will always make the more burdensome method unnecessary, and hence unconstitutional.

Returning to the interpretation of Levy suggested by the Louisiana court, the use of status of birth as an indirect test of dependency is both unnecessary and imprecise. ${ }^{79}$ Since illegitimacy, like race, must be considered a suspect classification ${ }^{80}$ the Louisiana interpretation is unconstitutional on this basis also.

A final difficulty with the Levy opinion is its failure to deal separately with the survivorship provision of the Louisiana statute. ${ }^{81}$ In a survivorship action, the amount of damages is fixed by the claim, based on pain and suffering, which the mother had at her death. Consequently, allowing illegitimate children to recover necessarily reduces the share of any legitimate children. This is not true in a wrongful death action, where the damages recoverable are those individually suffered by each child. Because of the possibility of prejudice to legitimate children, the survivorship provisions are arguably justified by two additional policies, "family unity" and "presumed intent."

The "family unity" policy is based on the assumption that illegitimate children are not usually part of a parent's family unit, and, hence, that the protection of their interests is somehow less important to society. The basis of this assumption is highly doubtful: many illegitimate children are treated as equal members of the family, especially in their relationships with their mother. In the Levy case itself, Justice Douglas noted the close relationship between the children and their mother. ${ }^{82}$ Even if most illegitimate children were not members of their parents' family circles (as may be true with their fathers), the "family unity" argument would still fail. Since some illegitimate children enjoy a close parental relationship and some legitimate children do not, the intimacy of such relationship, like actual dependency, ${ }^{\mathrm{s}}$ cannot be accurately measured by status of birth. Accordingly, if a state wants to make rights dependent on family intimacy, it must measure that quality directly.

The "presumed intent" theory derives from the fact that the survivorship aspect of the Louisiana statute is similar to intestate suc-

79 See text accompanying notes 64-78 supra.

so See text accompanying notes $30-41$ supra.

81 This provision is set forth in note 12 supra.

82391 U.S. at 72.

83 Text accompanying notes 64-78 supra. 
cession in that it involves the statutory transfer of property which the deceased owned at his death. Such a provision may embody a legislative attempt to distribute the property as the deceased would have wished if he had had an opportunity to express himself. ${ }^{44}$ Under this theory, the presumed desire of parents to exclude their illegitimate children from recovery would explain the classification. Nevertheless, this explanation is constitutionally inadequate to permit the result. First, since the rule burdens members of a suspect classification, the state must demonstrate that the legislative presumption with respect to the intent of decedents is reasonable. The principle is well established that there must be a rational relationship between the fact proven and the fact to be presumed. ${ }^{85}$ This may not be possible. Second, even if it is reasonable to presume that the deceased intended to exclude their illegitimate children from recovery, court enforcement of the discriminatory intent of decedents arguably constitutes invalid "state action" under Shelley v. Kraemer. ${ }^{86}$ In Shelley, the Court held that equal protection prohibits enforcement by the courts of restrictive covenants based on race. While this rule has been subject to diverse interpretation and discussion, ${ }^{87}$ its application here may be appropriate since the state is in some sense fostering discrimination by attributing an invidious intent to those who may not in fact have it. 88

It could be argued that both the "family unity" and "presumed intent" theories were considered in Levy as general justifications for the survivorship aspect of the statute, and that they were therefore implicitly rejected. Since Louise Levy had no legitimate children, however, a more reasonable conclusion is that the Court failed to discuss these theories, because it considered them irrelevant on the particular facts of the case. Accordingly, the question should still be considered open in cases where legitimate children are present, but the above analyses should be dispositive.

The Glona case presented a reverse fact pattern-the mother of an illegitimate child sought to recover for her child's wrongful death.

84 Intestacy legislation may alternately reflect a related policy of distributing property on the basis of a social plan which society deems fairest. Text accompanying notes 155-156 infra.

85 See, e.g., Tot v. United States, 319 U.S. 463 (1943) ; Western \& Atl. R.R. v. Henderson, 279 U.S. 639 (1929); Manley v. Georgia, 279 U.S. 1 (1929); McFarland v. American Sugar Ref. Co., 241 U.S. 79 (1916).

86334 U.S. 1 (1948).

87 See, e.g., Henkin, Shelley v. Kraemer: Notes for A Revised Opinion, $110 \mathrm{U}$. PA. L. Rev. 473 (1962) ; Horowitz, The Misleading Search for "State Action" Under the Fourteenth Amendment, 30 S. CAL. L. Rev. 208 (1957) ; Pollak, Racial Discrimination and Judicial Integrity: A Reply to Professor Wechsler, 108 U. PA. L. Rev. 1, 12-13 (1959); Wechsler, Toward Neutral Principles of Constitutional Law, 73 HARV. L. REv. 1, 29-30 (1959).

${ }^{88}$ Cf. Reitman v. Mulkey, 387 U.S. 369 (1967). 
Thus, although the discrimination complained of was based on illegitimacy, the case was different from Levy in that the parent of the illegitimate, and not the innocent child, stood to lose by the state action..$^{99}$ The policy of deterrence therefore had at least a colorable basis. Nevertheless, the Court again found

no possible rational basis . . . for assuming that if the natural mother is allowed recovery for the wrongful death of her illegitimate child, the cause of illegitimacy will be served. It would, indeed, be farfetched to assume that women have illegitimate children so that they can be compensated in damages for their death. A law which creates an open season on illegitimates in the area of automobile accidents gives a windfall to tortfeasors. But it hardly has a causal connection with the "sin," which is, we are told, the historic reason for the creation of the disability.

In finding "no rational basis" for the classification, the Court did not apply the strict test of equal protection. ${ }^{91}$ On the other hand, Justice Douglas specifically rejected the argument "that since the legislature is dealing with 'sin,' it can deal with it selectively and is not compelled to adopt comprehensive or even consistent measures." ${ }_{22}$ In sum, the Court appears to have taken a middle ground: a classification based on illegitimate parenthood is perhaps less suspect than one based on status of birth, but more so than one involving mere economic regulation, where the Court has approved "selective . . . measures." 93

We believe that classifications based on illegitimate parenthood should be constitutionally suspect. While parents of illegitimates have had the opportunity to avoid their status, like their children they suffer from a history of prejudice; ${ }^{94}$ and like their children, they are an "insular minority" unable to defend themselves through the political process. Finally, even assuming that the state can constitutionally regulate extramarital sexual activity, ${ }^{95}$ it should be required to proceed with care in an area where both intimate human relationships and longstanding prejudice are involved.

A further constitutional argument against discrimination based on producing illegitimates-the right to privacy-derives some support

89391 U.S. at 75.

$80 \mathrm{Id}$.

91 Id. at 70-71.

82391 U.S. at 75. The Court recognized the additional danger that "[o]pening the courts to suits of this kind may conceivably be a temptation to some to assert motherhood fraudulently," but held that this problem concerned "burden of proof" and, therefore, was not a sufficient ground for upholding the Louisiana classification. Id. at 76 .

93 E.g., Williamson v. Lee Optical Co., 348 U.S. 483 (1955).

94 See sources cited note 2 supra.

95 See text accompanying notes 96-104 infra. 
from the Glona opinion. At the heart of the state's position in both Levy and Glona is its asserted power to deter illegitimacy by limiting sexual intercourse to married couples. But it is arguable that the "zone of privacy" in the area of sexual relationships in marriage which was recognized by the Supreme Court in Griswold v. Connecticut ${ }^{98}$ should include private sexual activity between consenting adults. Although seven Justices of the Court in four opinions had difficulty articulating a rationale for the result in Griswold, ${ }^{97}$ the lowest common denominator of their views is that the fourteenth amendment protects certain intimate personal relationships from governmental intrusion. ${ }^{98}$ The need for this protection has been described by one commentator as follows:

[A] freedom to determine the extent to which others may share in one's spiritual nature, and the ability to protect one's beliefs, thoughts, emotions, and sensations from unreasonable intrusions are of the very essence of life in a free society. ${ }^{99}$

If privacy in sexual relationships between consenting adults is constitutionally protected, the state may not intrude unless it can demonstrate a "compelling interest." 100 The primary interest asserted, of course, is the deterrence of illegitimacy. But what are the states' more specific interests in that policy? Although a state might have a financial interest if illegitimate children were more likely to become public charges than legitimate children, it can protect its purse by "less drastic means" 101 than depriving parents of illegitimate children of rights of action, prominent among which is the enforcement of support statutes against fathers of illegitimate children. The more important policy is promotion of the family as an institution. But, since the state has already stated that unmarried parents both have a duty of support, and since, in many instances, they provide the same love and devotion as married parents, the state's interest appears to be in formal marriages as such. However, the dangers to the public which would result from substantial decrease in formal marriages are as yet undocumented. Moreover, in Glona and Levy, Louisiana's willingness to allow a parent to "cure" his sin through acknowledgment, undermines their claim of a

96381 U.S. 479 (1965).

97 Id. passim.

98 Although Griszold can be limited on its face to protect only actions between people who are married and are in the privacy of their own homes, the Court has recently shown that they do not consider the marital relationship crucial to matters of sexual privacy. Stanley v. Georgia, 394 U.S. 557 (1969).

99 Beaney, The Griswold Case and the Expanding Right to Privacy, 1966 WIs.

I. REv. 979, 995. See also, Emerson, Nine Justices in Search of A Doctrine, 64 MicH.

L. Rev. 219, 229 (1965); Freid, Privacy, 77 YaLe L.J. 475 (1968).

100381 U.S. at 502, 504 (White, J., concurring).

101 See 381 U.S. at 486, 497-98 (Goldberg, J., concurring), 502, 504 (White, J., concurring). 
substantial state interest in regulating the sexual relationship which produced the child.

The question whether formal marriage promotes the interests traditionally associated with that institution is outside the scope of this paper, but it certainly is subject to reexamination in light of developing concepts of individual freedom and morality. Increasingly the right of government to prohibit or discourage "immoral" conduct which damages no other public interest has been seriously challenged. The reporters of the Model Penal Code, for example, concluded that laws enforcing purely moral standards raise both constitutional and practical problems in a diverse society, and are therefore "inappropriate for government . . . 102 Similarly, the British Wolfenden Commission decided that the "realm of private morality [is] . . . not the law's business." 103

Although Justice Douglas did not discuss the right to privacy in Glona, he implicitly questioned whether the state has a proper interest in deterring illegitimacy. He twice placed quotation marks around the word "sin" in using it to describe the state's interest in controlling the behavior of the parents, thus questioning the validity of the state's power in this area and perhaps raising the issue whether the Griswold "privacy" theory may not be relevant. ${ }^{104}$ As with the due process suggestions in Levy, however, the Court did not elaborate, thus leaving this issue open.

Justices Harlan, Black and Stewart dissented from both decisions in a single opinion. ${ }^{105}$ They disagreed with the majority on two fundamental points. First, Justice Harlan, writing for the three dissenters, denied that the classification at issue in the cases (" $[t]$ he difference between a child who has been formally acknowledged and one who has not" ${ }^{106}$ ) was inherently suspect, and therefore rejected the strict standard of equal protection adopted by Justice Douglas. While Justice Harlan seems correct in dealing with the basis of the classification rather than the nature of the right, he failed to recognize the invidious results of the requirement of acknowledgement-depriving a child of rights that he would otherwise have because of something as completely beyond his control as the color of his skin. Surely, the dissenters would not tolerate a wrongful death statute which denied re-

102 Moder Penal Code $\$ 207.1$, Comment (Tent. Draft No. 4, 1955).

103 Dworkin, Lord Devlin and the Enforcement of Morals, 75 YaLE L.J. 986, 990 (1966).

104391 U.S. at 75.

$105 I d$. at 76. For an excellent analysis of Justice Harlan's dissent, see Krause, Legitimate and Illegitimate Off spring of Levy v. Louisiana-First Decisions on Equal Protection and Paternity, 36 U. CHr. L. REv. 338, 342-45 (1969).

106391 U.S. at 81. 
covery to blacks, but they failed to discuss how illegitimates were in any different constitutional posture. ${ }^{107}$

Second, Justice Harlan argued that the discrimination does serve rational purposes. To begin with, it enforces the formalities of marriage and acknowledgement:

If it be conceded, as I assume it is, that the State has power to provide that people who choose to live together should go through the formalities of marriage and, in default, that people who bear children should acknowledge them, it is logical to enforce these requirements by declaring that the general class of rights that are dependent upon family relationships shall be accorded only when the formalities as well as the biology of those relationships are present. ${ }^{108}$

Justice Harlan's implicit argument that a state should be able to justify an individual discrimination in the context of its overall statutory scheme without having to demonstrate that each individual discrimination constitutes a reasonable deterrent seems correct. This argument, however, does not meet all of the objections raised against the Louisiana scheme. First, with respect to discrimination against the illegitimate child, no answer is provided for the due process objection to the requirement of acknowledgement. ${ }^{109}$ But even where the discrimination is directed at the parent of the illegitimate instead of the innocent child, Justice Douglas correctly pointed out that Louisiana's sanctions against illegitimates are neither "comprehensive [n]or even consistent," 110 especially since any parent who is aware of the law need not suffer any disadvantage from his child's illegitimacy because he is allowed to acknowledge the child and enjoy the resulting benefits. Finally, even if a state had a comprehensive scheme of sanctions, the deterrent theory would probably still be "farfetched." 111 The fear of a potential illegitimate parent that neither he nor his child could benefit from the other's death under wrongful death, inheritance, or welfare provisions is probably not substantial enough to constitute a reasonable deterrent.

Justice Harlan would also uphold the Louisiana statute on the ground that "a State may choose to simplify a particular proceeding

107 The dissent suggests that a state may classify persons "in terms of their legal rather than their biological relation." Id. at 79. This statement is meaningless. As Justice Douglas answered, "To say that the test of equal protection should be the 'legal' rather than the biological relationship is to avoid the issue. For the Equal Protection Clause necessarily limits the authority of a State to draw such 'legal' lines as it chooses." Id. at 75-76.

$108 I d$. at 80.

109 Text accompanying note 107 supra.

110391 U.S. at 75.

111 Id. 
by reliance on formal papers rather than a contest of proof." 112 This proposition raises the question whether substantive rights (here the right to recover for wrongful death) can be denied because of problems of proof and the danger of fraudulent claims. Again, since acknowledgment is beyond the control of illegitimate children, any formal requirement with respect to their claims would be the practical equivalent of a total bar. Since due process is not offended where the discrimination is directed against the parent of the illegitimate, it could be argued that the enforcement of the requirement of acknowledgment against him is not unreasonable. Nevertheless, the majority in Glona specifically held that the danger of fraudulent claims in this context can only be dealt with by imposing an appropriate burden of proof. ${ }^{113}$ This seems correct since the danger of fraud by either the parent or the child is not serious in cases involving maternal relationships because the same records normally exist whether or not the mother is married. The more difficult problems involved in proving paternity will be discussed below. ${ }^{114}$

\section{The Effect of Levy and Glona on Other Forms of Discrimination Against Illegitimates}

The broad language of the Court in the Levy and Glona opinions indicates the beginning of a general change in the legal status of illegitimates. While the decisions were tied to the particular statute, ${ }^{115}$ Justice Douglas made no apparent effort to limit their effect, although the Court had been informed of the nature and extent of other discriminations against illegitimates. ${ }^{116}$ Levy and Glona leave open significant questions because the majority did not grapple with the more difficult issues presented, and because the cases did not involve all the policies which might be offered to justify classification on the basis of illegitimacy. But the application of the principles established by the Court to the undecided issues should lead to the end of all the major legal disadvantages under which illegitimates now suffer.

\section{A. Support}

Discrimination in the area of parental support is perhaps the most fundamental disability imposed on illegitimate children, since the duty

$112 I d$. at 80.

113 Id. at 76.

114 Text accompanying notes 124-134 infra.

115391 U.S. at 69 n.1.

110 In response to a request by Justice Fortas during oral argument, counsel for appellants in Levy filed a supplemental memorandum of law outlining the nature and extent of discriminations against illegitimate children in state law. Federal law affecting illegitimates was discussed in the Brief for Appellants at $11 \mathrm{n.7}$, Levy v. Louisiana, 391 U.S. 68 (1968). 
of support initially defines the legal relationship between the child and his parents. Although mothers apparently owe their illegitimate children support in all states, ${ }^{117}$ fathers escape any liability in some states, ${ }^{118}$ and in one the duty attaches only after acknowledgement. ${ }^{119}$ But even where the duty is owed, it is likely to be less extensive for illegitimate children than for legitimate ones. In some states, for example, a child's right to support ends at a younger age if he is illegitimate. ${ }^{120}$

The denial to an illegitimate child of equal rights to parental support cannot be justified under Levy. The denial clearly does not deter illegitimacy; indeed, to allow a parent to escape his usual liability could have the opposite effect. On the other hand, the "family unity" policy might be asserted to justify discrimination in regard to the duty to support. With respect to the mother, the justification is no more convincing here than it was in the wrongful death situation. ${ }^{121}$ With respect to the father, although the family unity argument appears to be stronger since illegitimate children are usually not members of his immediate family circle, the existence of an intimate relationship is irrelevant to the purpose of support statutes: guaranteeing children a minimum standard of living. A child may be equally destitute inside or outside the family circle. Legitimate children, although not living with their fathers, are entitled to a full right to support.

It is also evident that the goals of simplifying proof and preventing fraud cannot justify the discrimination, at least with respect to support from the mother. The danger of fraud is not greater in this situation than it was in Glona where the Court explicitly held that the possibility of fraudulent assertion of motherhood could only be dealt with by burden of proof. ${ }^{122}$ In fact, there is probably less danger in an assertion of relationship by a child against a living mother than in a claim of parenthood by a mother with respect to a deceased daughter. The fact that if the claim of the "daughter" is fraudulent it will threaten the interests of an innocent woman, instead of a tortfeasor as in Glona, is too minor a distinction to justify a different result, especially since the problem of proof is not substantial with respect to motherhood. ${ }^{123}$

The difficulties of proof are more serious, however, with respect to the father. Although the development of increasingly sophisticated

117 No state has held to the contrary. See 10 Am. Jur. 2d Bastards $\S 67$ (1963).

118 See Krause, Equal Protection for the Illegitinate, 65 MIcH. L. REv. 477, 478 (1967).

119 VA. CODE ANN, \$20-61.1 (1960).

120 See Krause, Bringing the Bastard into the Great Society-A Proposed Uniform Act on Legitimacy, 44 TEx. L. REv. 829, 850-52 (1966).

121 Text accompanying note 83 supra.

122391 U.S. at 76.

123 See text accompanying note 113 supra. 
blood tests has somewhat eased the problem, proof of paternity still involves considerable danger of fraud and inconclusiveness of evidence. ${ }^{124}$ Blood tests can prove the innocence of fifty per cent of those men falsely accused of bastardy. ${ }^{125}$ They cannot, however, demonstrate conclusively that a given individual is the father, only that he is in the half of the male population that could be. But can this greater uncertainty of parentage justify a rule which denies the illegitimate child equal substantive rights?

It is submitted that Lezy and Glona, though involving a maternal relationship, establish the general principle that, where illegitimacy is involved, a state cannot deny equal substantive rights when other, less drastic means are available by which it can prevent fraud. Here, the state can require claimants to satisfy an appropriate burden of proof. ${ }^{120}$ Under the Levy rationale, the denial to an illegitimate child of the right to full support from his father must be considered a violation of the "basic civil rights." 127 The illegitimate child's right to his father's support is certainly at least as fundamental as his right to recover for the death of his mother. In addition, the discrimination embodies the suspect classification of ancestry. Consequently, the state must adopt the least burdensome method of protecting its legitimate interests. ${ }^{128}$ Here the least drastic way of preventing fraudulent claims is reliance on an appropriate burden of proof.

Assuming that a state does use burden of proof, are there any constitutional limitations on how heavy a burden may be imposed? One state now conditions paternal support on acknowledgment in open court. ${ }^{129}$ While this requirement might be considered a form of burden

124 The danger of a jury finding in favor of a "wronged woman" despite strong evidence to the contrary is illustrated by the famous case of Berry v. Chaplin, $74 \mathrm{Cal}$. App. 2d 652, 169 P.2d 442; 74 Cal. App. 2d 669, 169 P.2d 453 (1946), in which Charlie Chaplin was found to be the father of a child although blood tests excluded the possibility of his paternity. For further discussion of blood tests see sources cited in note 125 infra.

An extreme case of uncertainty of evidence occurs when several men have had "access" to the mother. One solution to this special problem is the imposition of joint liability on the possible fathers. See Note, Liability of Possible Fathers: $A$ Support Remedy for Illegitinnate Children, 15 U.C.L.A. L. REv. 859 (1966).

125 Schatkm, Disputed Paternity Proceedings 158-59 (2d ed. 1947). The accuracy of blood tests used to exclude the possibility of the paternity is analyzed minutely in Ross, The Value of Blood Tests as Evidence in Paternity Cases, 71 HARV. L. Rev. 466 (1958). See also Note, Blood Grouping Tests and the New Kentucky Solution, 53 KY. L.J. 790 (1965).

Technological development may some day make proof of paternity routine, see Krause, sipra note 118, at 491, but at present some states do not even allow blood test evidence to be used to exclude the possibility of fatherhood. See Foote, SANDER, \& LeVY, Cases on Faniny Law 50 (1966).

126 See Glona v. American Guarantee \& Iiability Insurance Co., 391 U.S. 73,

76 (1968). See also text accompanying note 175 infra.

127391 U.S. at 71.

128 Text accompanying notes 64-78 supra.

129 Under VA. CODE ANN. \$20-61.1 (1960) acknowledgment must be in open court. 
of proof, it is tantamount to no legally enforceable right to support, since it depends on the voluntary act of the father. Other states make actions for paternal support criminal and require proof beyond a reasonable doubt. ${ }^{130}$ Still others demand "clear and convincing evidence of paternity. ${ }^{131}$

Such burdens raise a different equal protection problem: is the danger of fraud in paternal support actions by illegitimate children sufficiently great to justify a higher evidentiary standard? It is doubtful that evidence in paternity proceedings is significantly less certain than proof in other areas of factual dispute, for example, eyewitness identification. ${ }^{132}$ But it would probably be difficult to establish this theory since the courts have traditionally been reluctant to impose constitutional limitations on state rules of evidence except where explicit rights are involved. ${ }^{133}$ Nonetheless, courts might be forced to adopt this reasoning if a state established a standard of proof so severe that most illegitimates were barred from recovery. ${ }^{134}$

Since the Levy decision, courts in four states have considered the question of the illegitimate child's right to paternal support. Three courts have held that Levy requires the full equality of illegitimates; one decision is to the contrary.

In $R . v . R .{ }^{135}$ the Missouri Supreme Court overturned a wellestablished rule denying illegitimate children any right to support from their fathers. A lower court dismissed a petition for support without adjudicating the disputed issue of paternity. ${ }^{136}$ Reversing, the Supreme Court said that

[t] he principles applied by the United States Supreme Court [in Levy] would render invalid state action which produces discrimination between legitimate and illegitimate children insofar as the right of the child to compel support by his father is concerned. Under the guise of discouraging illegitimacy, states may no longer cast the burden upon the innocent child.

The decisions of the United States Supreme Court compel the conclusion that the proper construction of our statutory

130 See, e.g., Commonwealth v. Watts, 179 Pa. Super. 398, 116 A.2d 844 (1955).

131 See, e.g., McNeil v. McNeil, 166 Iowa 680, 148 N.W. 643 (1914).

132 See P. Wall, Eyewitness Identification in Criminal Cases (1965). See also United States v. Wade, 388 U.S. 218 (1967).

133 See, e.g., Spencer v. Texas, 385 U.S. 554 (1967).

134 Cf. Trent v. Loru, 57 Misc. 2d 382, 388, 292 N.Y.S.2d 524, 530 (Bronx County Family Ct. 1968), in which the court gave a loose interpretation to a New York acknowledgment provision "with the objective of removing so far as possible the obstacles to equal treatment of the illegitimate with the legitimate child. See Levy v. Louisiana . . . ."; cf. Commonwealth v. Dillworth, 431 Pa. 479, 246 A.2d 859 (1968). 135431 S.W.2d 152 (Mo. 1968).

136 Id. at 153 . 
provisions relating to the obligations and rights of parents . . affords illegitimate children a right equal with that of legitimate children to require support by their fathers. ${ }^{137}$

While the Court's decision is correct on the basis of the analysis above, its application of Levy was mechanical; like Justice Douglas, the Missouri court failed to deal with the more complex issues in the case.

In Storm v. None, ${ }^{13 s}$ the Family Court for New York County challenged all aspects of a New York law that gave illegitimates the right to support but only with substantive and procedural disadvantages not faced by legitimate children. The court cited Levy and noted that nowhere was discrimination more suspect than in the area of support. ${ }^{139}$

The Colorado Supreme Court was faced with a slightly different problem in Munn v. Munn. ${ }^{140}$ At issue was a statute making a jury verdict for support final except where legitimate fathers could demonstrate changed circumstances. The court observed that the inflexible support provision was "equally objectionable from the illegitimate child's point of view," 141 and further stated:

Levy and Glona point the way to the inescapable conclusion that the support obligation owed by a father to his legitimate child cannot differ substantially from the duty owed to his illegitimate child. ${ }^{142}$

Finally, in Baston v. Sears, ${ }^{143}$ the Ohio Supreme Court, by a 4-3 vote, denied an illegitimate child paternal support. ${ }^{144}$ Levy had been decided by the United States Supreme Court after argument in Baston, and the Ohio majority dismissed the case in a footnote on the ground that it was "based on the intimate, familial relationship which exists between a mother and her child, whether the child is legitimate or illegitimate."145 The court went on to reject the equal protection argument on the novel ground that no state action was involved because the right to paternal support existed only as a result of

the voluntary contract which is undertaken when marriage occurs. That contract includes, by way of well understood

137 Id. at 154 (citations omitted).

13857 Misc. 2d 342, 291 N.Y.S.2d 515 (New York County Family Ct. 1968).

$139 \mathrm{Id}$. at 346-47, 291 N.Y.S.2d at 519-20.

140 - Colo. - 450 P.2d 68 (1969).

141 Id. at,- 450 P.2d at 69 .

$142 I d$.

14315 Ohio St. 2d 166, 239 N.E.2d 62 (1968).

$144 I d$. at 168,239 N.E.2d at 63.

145 Id. 
tradition and custom, the promise by the husband to support children which may result from this relationship which is favored by the law and public policy. ${ }^{146}$

This argument seems entirely unfounded. Not only is the husband's duty to support imposed by statute in Ohio, ${ }^{147}$ but the majority opinion itself states that the marital relationship is "favored by the law," showing clearly that there is state action involved. The dissent in Baston saw no problems in the direct application of Levy. ${ }^{148}$

\section{B. Inheritance}

\section{By Illegitimate Children}

Another important area of discrimination is that of inheritance. Only Louisiania denies illegitimate children equal rights of inheritance from their mother, ${ }^{149}$ but only two states grant equal rights of inheritance from the father. ${ }^{150}$ Eighteen more give full rights to acknowledged illegitimates. ${ }^{151}$ Four states expressly adopt the common law rule of no inheritance; the rest have not ruled on the issue. ${ }^{152}$ The illegitimate's rights to inherit from his maternal and paternal kin are even more limited. ${ }^{153}$ Furthermore, most states have ruled that the word "children" in a will does not include illegitimates unless contrary intent is shown. ${ }^{154}$

The major disadvantage to illegitimates in inheritance involves intestate succession. Intestacy provisions may embody two related, but potentially conflicting, policies: distributing property as society deems fair, and distributing property according to the presumed intent of the deceased. If a socially equitable allocation were the only purpose of an intestacy statute, discrimination could not be justified. At a minimum, Levy establishes that a state cannot decide constitutionally that illegitimate children are less deserving merely because of their condition of birth. The "family unity" policy is no more convincing here than

146 Id. at 168,239 N.E.2d at 63-64.

147 Orio Rev. Code Ann. $\$ 3103.03$ (Page 1960) ; cf. Murphy v. Quigley, 5 Ohio Dec. 680 (1900), aff'd, 65 Ohio St. 598 (1901).

14815 Ohio St. $2 \mathrm{~d}$ at 170-71, 239 N.E.2d at 64-65 (O'Neill, J., dissenting).

I49 Note, Illegitimacy, 26 BRookLyN L. REv. 45, 76-79 (1959). Since publication of this note, New York law has been changed to give illegitimate children full rights of inheritance from their mothers. N.Y. EsTates, PowERS \& TRUST L. \$4-1.2 (McKinney 1967).

150 See, Note, Illegitimacy, supra note 149 , at 76-79.

151 Id.

152 Id.

$153 I d$.

15495 C.J.S. Wills $\S 652$ (1957). 
it was with respect to wrongful death. If establishing a "presumed intent" is a purpose of intestacy provisions, the discussion above of this policy should also govern here. In fact, the argument that Shelley $v$. Kraemer ${ }^{155}$ forbids a presumption of discriminatory intent is even stronger here since a deceased normally could have excluded illegitimate children by will. ${ }^{156}$

Intestate succession from the father raises a further problem: some states provide that for purposes of inheritance paternity must be established during a relatively short period before or after the birth of the illegitimate child; ${ }^{157}$ another occasional requirement is that paternity be proven before the death of the father. ${ }^{158}$ Such provisions have the understandable purposes of insuring that the issue be tried while the evidence is fresh and that the man "accused" have an opportunity to be present. The effect of these statutes, however, is to forfeit an infant's future rights because of the inaction or insufficient action of his mother, who may often be unaware that anything beyond her own right to support was at stake. ${ }^{159}$ Such statutes raise in a new context the due process question whether a child can be denied rights because of the failings of another person. While a number of courts have held that a statute of limitations can run against an infant, ${ }^{160}$ the constitutionality of these holdings has apparently never been considered by the United States Supreme Court. ${ }^{161}$ The argument for unconstitutionality is particularly strong here. First, the child is disadvantaged under a suspect classification. But more important, a mother may have interests conflicting with those of her illegitimate child. For example, she might wish to avoid the public embarrassment of a paternity proceeding, or a strong, remaining emotional attachment to the father may stop her from bringing the action. For these reasons, in order to cut off the future rights of an illegitimate child, the state should be required to hold a hearing in which independent representation is provided for the child.

The denial to illegitimate children of the right to inherit from maternal and paternal kin is perhaps of minor practical importance. But because no additional justifications for this discrimination seems

155334 U.S. 1 (1948).

156 See Krause, supra note 118 , at 502.

157 E.g., N.Y. Estates, Powers \& Trust L. §4-1.2(2) (McKinney 1967).

158 Id.

159 Minnesota has attempted to alleviate this problem by allowing the commissioner of public welfare to bring paternity actions to protect the future interests of illegitimate children. MnNN. Srat. ANn. \$2 257.33 (1959).

100 See 54 C.J.S. Limitation of Actions $\$ 235$ (1948). See also Pittman v. United States, 210 F. Supp. 763 (N.D. Cal. 1962).

101 See 54 C.J.S. Limitations of Actions $\$ 235$ (1948). 
available, it should also fall under Levy, subject to proof of fatherhood in the case of paternal relationship.

By chance, the first application of Levy came in a case in which the right to inherit from maternal kin was denied to an illegitimate child of the mother and to the descendants of her other illegitimate children. In Michaelsen v. Undhjem, ${ }^{162}$ the Supreme Court of North Dakota held that the statute denying recovery to the illegitimate child and his descendants was unconstitutional under Levy. The court said:

Applying the reasoning in Levy, as no action, conduct, or demeanor of the illegitimate children in the instant case is relevant to their status of illegitimacy, we conclude that the classification for purposes of inheritance contained in $\S 56-01-05$, which is based on such a status . . . is unreasonable. ${ }^{103}$

The court also stated that the statute

which punishes innocent children for their parents' transgressions, has no place in our system of government, which has as one of its basic tenets equal protection for all. ${ }^{104}$

Although equal protection was the ground for decision, the court's language also supports the due process argument. In a manner similar to the United States Supreme Court, however, the North Dakota court failed to deal with the family unity and presumed intent arguments which could have been raised with respect to inheritance. ${ }^{165}$

A somewhat different set of problems is raised by decisions creating a presumption that a disposition to "children" does not include illegitimates. While these decisions, like intestacy provisions, presume a discriminatory intent, the burden on illegitimates is less serious since the presumption is rebuttable. An illegitimate who had lived with his father, for example, could probably recover under a will leaving property to "children." If it can be shown that the presumption has a factual basis and if rebuttal is not made unreasonably difficult, this may be one classification based on illegitimacy which is still constitutional after Levy.

\section{From Illegitimate Children}

At common law, the rule was that parents were not heirs of their illegitimate children. ${ }^{166}$ This rule, which is still in effect in many

162162 N.W.2d 861 (N.D. 1968).

$163 \mathrm{Id}$. at 878 .

$164 I d$.

165 Invalidating the discriminatory provision, the court held that the plaintiffs were entitled to recover by the underlying statute. $I d$. at 879 .

166 Annot., 48 A.L.R.2d 759, 761 (1956). 
states, ${ }^{107}$ is now constitutionally invalid under Glona, since none of the possible justifications for the rule is supportable. Most obviously, the theory that the conception of illegitimate children would be deterred by this rule is untenable, especially since a parent normally inherits only if the child died intestate without descendants. ${ }^{168}$

A more plausible argument is that the state could condition inheritance by a parent on prior acknowledgment in order to encourage parents to acknowledge. Even if the rationality of this deterrent is unconvincing, it can also be argued that a person who has refused to admit parenthood when the admission might have been costly should be estopped to claim the relationship when it has become advantageous. If, however, the underlying purpose is to punish parents who fail to accept their responsibilities, the rule denying inheritance to parents of illegitimates who fail to acknowledge is imprecise and unnecessary. ${ }^{169}$ Not all parents who fail to acknowledge formally have shirked their duties, as the case of Louise Levy well illustrates. In addition, those parents of legitimate children, who desert their children, can still inherit. Because of this imprecision, a state cannot equate a failure to acknowledge with desertion. Instead, it must proceed against unworthy heirs generally without regard to illegitimacy.

The "presumed intent" justification seems unavailable here because it is difficult to imagine to whom, other than his parents, an illegitimate child with no descendants would want his estate to go. Even the usual argument that an alleged father's paternity should be clearly proven in order to protect him is less substantial since it is the father himself who is asserting the relationship.

A less significant form of discrimination denies intestate rights to the legitimate siblings of illegitimate children. ${ }^{170}$ For the reasons mentioned above, this rule also lacks validity under Levy and Glona.

\section{Benefit Distribution Statutes}

Discrimination is also embodied in many of the state and federal laws which allocate income or benefits. ${ }^{171}$ While only Louisiana denied

$167 \mathrm{Id}$. at 762-64, 774-77. However, in other states it is modified. Id. at 782-85 (mother), 796-97 (father).

168 26A C.J.S. Descent and Distribution $\$ 33$ (1956).

169 See text accompanying notes $64-78$ supra.

170 Annot., sipra note 166 , at 795-96.

171 Illegitimate children have been the victims of various rules intended to prevent them from receiving public assistance benefits. See the discussion of the "suitable home" plan in note 39 supra.

A newer version of the "suitable home" requirement is the "substitute father" regulation, whereby families receiving aid for families with dependent children are totally or partially denied benefits when it can be shown that the mother had sexual relations with a man in or outside her home. The birth of an illegitimate child is 
illegitimate children wrongful death recovery from their mothers, ${ }^{172}$ most states give them no action for their fathers' deaths. ${ }^{173}$ Courts in two states have recently dealt with the question of an illegitimate child's right to recover for his father's death; both allowed recovery. In Armijo v. Wesselius, ${ }^{174}$ decided shortly after Levy and Glona, the Supreme Court of Washington recognized strong social and constitutional policies in opposition to discrimination against illegitimate children and interpreted the wrongful death statute to include them. The Court rejected the argument that the danger of fraud required the opposite result, reasoning that "the burden of proof, as in other law suits, will provide estates ample protection." 175

In a later case, Schmoll v. Creecy, ${ }^{176}$ the Supreme Court of New Jersey held that the state's wrongful death provisions, which explicitly adopted an intestacy rule denying illegitimate children rights with respect to their fathers, were unconstitutional under Levy. Distinguishing the case from the intestacy situation, in which the court believed "presumed intent" might raise an additional problem, ${ }^{177}$ the court held that status of birth was irrelevant to the damage done to the child whichever parent was involved. The court did not discuss proof of paternity, probably because it was indisputable on the facts. ${ }^{178}$

Most states also deny wrongful death recovery to the parents of an illegitimate child. ${ }^{179}$ Since the legal issues are parellel to those raised with respect to inheritance from illegitimate children, this rule should also fall under Glona.

Another discrimination is found in workmen's compensation statutes: illegitimate children can often recover only if they can prove actual dependency, while legitimate children usually benefit from a conclusive presumption of dependency. ${ }^{180}$ As discussed above, this linking of dependency and legitimacy is both imprecise and unnecessary and should fall on those grounds.

considered prima facie evidence of the existence of a "substitute father." In King v. Smith, 392 U.S. 309 (1968), the Supreme Court held that Alabama's "substitute father" regulation requiring total denial of benefits violated the Social Security Act. A three-judge court below had enjoined enforcement of the regulation on equal protection grounds. 277 F. Supp. 31 (M.D. Ala. 1967).

172 See Annot. 72 A.L.R.2d 1235, 1236-37 (1960). Decisions in Georgia and Maryland which denied the recovery were overturned by statute. GA. CodE ANN. $\S 105-1306$ (1968); MD. ANN. Code art. 67, §4 (1967).

173 Annot., supra note 172 , at 1239.

174 - Wash. 2d -, 440 P.2d 471 (1968).

$175 \mathrm{Id}$. at -, $440 \mathrm{P} .2 \mathrm{~d}$ at 473 .

17654 N.J. 194, 254 A.2d 525 (1969).

177 Id. at $199-200,254 \mathrm{~A} .2 \mathrm{~d}$ at 528.

178 Id. at 199,254 A.2d at 527.

179 See 25A C.J.S. Death § 35 (1966).

180 See 99 C.J.S. Workmen's Compensation $\$ 141(2)(d), 141(3)$ (1958). 
Among federal statutes, ${ }^{181}$ the Longshoremen's and Harbor Workers' Compensation Act ${ }^{182}$ specifically allows recovery by illegitimate children only if they were acknowledged by, and dependent on, the deceased. This requirement raises the same issue of formal proof discussed with respect to Levy. ${ }^{183}$ The Federal Employees' Compensation Act, ${ }^{184}$ the Copyright Act, ${ }^{185}$ and the Federal Employees' Group Life Insurance Act ${ }^{188}$ have been held to incorporate state laws of inheritance, and thus discriminate against illegitimate children in a similar fashion. These provisions present constitutional questions identical to those raised by the state inheritance laws which they adopt, and should meet a similar fate under Levy.

The Fifth Circuit reached this result in Herbert v. Petroleum Pipe Inspectors, Inc. ${ }^{187}$ The representative of two illegimate children sued under the Jones Act ${ }^{188}$ which explicitly adopts the provisions of the Federal Employees' Liability Act. Although previous cases under the Jones Act held that illegitimates were entitled to recover as a matter of federal law, ${ }^{189}$ the district court granted summary judgment to the defendants on the ground that the illegitimates were not "children" under the Act, because they were adulterous bastards under Louisiana law. ${ }^{190}$ The circuit court reversed on the basis of Levy without further comment. ${ }^{191}$

In Haley v. Metropolitan Life Insurance Co., ${ }^{192}$ decided after Levy, a Missouri court held that an illegitimate child could recover for his father's death under the Federal Employees' Group Life Insurance Act. The court refused to apply Missouri law which would have disqualified the child, and instead adopted a federal definition of "children" including illegitimates. ${ }^{193}$ The court said that its decision to overrule prior cases referring to state law was "bolstered" by Levy. ${ }^{194}$

181 See generally, Note, The Rights of Illegitinates Under Federal Statutes, 76 HARV. L. REV. 337 (1962).

18233 U.S.C. $\$ \$ 901-50$ (1964).

183 Text accompanying notes $108-111$ supra.

1845 U.S.C. $\$ \$ 751-803$ (a) (1964).

18517 U.S.C. $\$ 24$ (1964).

1865 U.S.C. $\$ \$ 2091-103$ (1964).

187396 F.2d 237 (5th Cir. 1968).

18846 U.S.C. $\$ 688$ (1964).

189 See Civil v. Waterman S.S. Corp., 217 F.2d 94 (2d Cir. 1954) ; In re Estate of Wenkous, 158 Misc. 663, 286 N.Y.S. 518 (Surr. Ct. 1936). See generally Note, supra note 181, at 346-53.

100396 F.2d 237 (5th Cir. 1968).

191 Id.

192434 S.W.2d 7 (St. Louis Court of App. 1968).

193 Id.

194 Id. at 12 . 


\section{Public Housing}

Another common form of discrimination against illegitimates is the exclusion of families with illegitimate children from public housing. ${ }^{195}$ The constitutionality of this discrimination is complicated by several factors. First, the general question of the legality of the frequently arbitrary standards and procedures by which housing authorities accept and evict tenants is the subject of much current litigation. ${ }^{198}$ Consequently, the reasons for which a housing authority may exclude actual or prospective tenants are unsettled, other than for failure to meet income standards. Second, housing discrimination affects both parents and children so that aspects of both Glona and Levy are involved. A third complication is that the exclusionary policy often includes both rejection of applicants with illegitimate children and eviction of tenants who gave birth while in residence. These two factual settings involve somewhat different policy considerations.

A number of suits challenging housing discrimination have been filed, ${ }^{197}$ but only one has reached a decision on constitutional grounds. In Thomas v. Housing Authority, ${ }^{198}$ decided in 1967, the federal district court in Arkansas held that an automatic rejection of two housing applications on grounds that the mothers had illegitimate children violated the fourteenth amendment. It found such action to be in "general disharmony with the spirit and aim of the low-rent housing program." 199 In dictum, however, the court added that to insure the morality and lawful conduct of tenants, the housing authority "might permissibly formulate a policy giving some evidentiary or presumptive effect to the presence of illegitimate children." 200

195 Housing authorities in at least 12 states exclude families with illegitimate children. See Rosen, Tenants Rights in Public Housing, in HOUSING FOR THE POOR: RIGHTS AND REMEDIES 154, 227 n.170 (1967).

196 In Thorpe v. Housing Authority, 393 U.S. 268 (1969), the United States Supreme Court held that a circular recently issued by HUD to local housing authorities gave tenants the right to notice of the charges against them. See Holmes v. New York Housing Authority, 398 F.2d 262 (2d Cir. 1968). Other cases are noted in 13 WEL. L. BuLL., June 1968, at 15. See generally Note, Public Landlords and Private Tenants: The Eviction of "Undesirables" from Public Honsing Projects, 77 Y ALE L.J. 988 (1968) ; Freidman, Public Housing and the Poor: An Overview, 54 CALIF. L. Rev. 642 (1966); Rosen, supra note 195, at 154-250.

197 See, eg., Lewis v. Housing Authority, 397 F.2d 178 (5th Cir. 1968) (regulation requiring eviction of tenant who has an illegitimate child while in residence rescinded after action brought) ; Teasley v. Housing Authority, No. 68-950 (E.D. Pa., dismissed, June 7, 1968) (stipulation provides that illegitimacy is not a ground for refusing public housing applicants); Richardson v. Housing Authority, No. 678 (E.D. N.C., consent order filed, May 13, 1968) (consent order terminates policy of eviction for illegitimacy); Lewis v. Housing Authority, No. 7-C-355 (E.D. Wis., filed Oct. 31, 1967) (suit attacks unwritten policy of eviction for having more than one illegitimate child).

198282 F. Supp. 575 (E.D. Ark. 1967).

$190 \mathrm{Id}$. at 580 .

200 Id. at 581 . 
The exclusion of applicants with illegitimate children involves a different use of the classification of illegitimacy than that considered in Levy and Glona. The Authority apparently did not suggest that its purpose was to deter illegitimacy. ${ }^{201}$ Indeed, the idea that the fear of a future inability to obtain public housing would help prevent the conception of illegitimate children is as "far-fetched" as the deterrence justification rejected in Glona. Rather, the defendants attempted to justify their policy on the ground that it was intended to prevent their buildings from becoming "hotbeds of delinquency." 202 They argued that the presence of illegitimate children indicated a danger of antisocial conduct in the future, which, in turn, justified rejection of the applications. Faced with this argument, the court concluded that while illegitimacy might be of some predictive value, as a sole basis for refusal it was insufficiently precise. ${ }^{203}$ Upon consideration of all relevant factors, some families with illegitimate children might be good tenants, while others without such children might prove poor ones. Accordingly, illegitimacy alone was not an adequate ground for exclusion; but it could be used as some evidence of a family's undesirability.

The Thomas holding should not be affected by Levy and Glona. Although the Thomas decision goes beyond the explicit holdings of the Supreme Court by relying on a theory of statutory imprecision to strike down a classification which the court believed did have some rational connection with the purposes of the housing program, this extension is appropriate. $^{204}$

In any event, the constitutional issue is now largely academic because of the recent mandatory circular, issued by the Department of Housing and Urban Development (HUD), prohibiting any exclusion based solely on illegitimacy. ${ }^{205}$ The circular quotes from the Thomas decision and apparently intends to adopt its result. ${ }^{206}$

A more difficult issue is the continuing validity of the dictum in Thomas that it is constitutionally permissible to consider illegitimacy as an unfavorable factor in a family applying for public housing. A housing authority might wish to prevent conduct which presents either a physical or a moral threat to other tenants. If physically disruptive behavior is the concern, exclusion for illegitimacy should clearly be unconstitutional. First, there is no reliable evidence that among eligible

201 Deposition of George Millar, Jr., Executive Director, Housing Authority of Little Rock, at 39, Thomas v. Housing Authority, 282 F. Supp. 575 (E.D. Ark. 1967). 202 Id.

203 Id. at $580-81$.

204 See text accompanying notes 77-78 supra.

205 Office of the Assistant Secretary for Renewal and Housing Assistance, Department of Housing and Urban Development, Circular, Dec. 17, 1968.

206 Id. passim. 
families, those containing illegitimate children are unusually likely to present this kind of threat. Mothers of illegitimate children do not differ significantly from mothers of legitimate ones, in either background or behavior. ${ }^{207}$ Another possibility is that illegitimate mothers are unable to prevent their children from disturbing others: but there is no indication that illegitimacy is relevant to a lack of parental discipline. $^{208}$ The lack of a father in the family may affect parental control, and since illegitimate fathers are normally absent, families containing illegitimate children may create special problems. ${ }^{209}$ The same, though, is true of families in which, although the children are legitimate, the father is missing. Yet these families are not affected by the illegitimacy exclusion. Thus, whether or not a housing authority could constitutionally rely on the absence of a father in refusing to accept applicants, it may not use the suspect classification of illegitimacy as an indirect way of considering that factor. Such a use of the classification is clearly imprecise because not all fatherless families include illegitimate children, and unnecessary because the state could consider paternal absence directly.

Second, even if the state could prove that illegitimacy was relevant to the danger of future misbehavior, it should not rely on status of birth as a factor justifying exclusion.210 There is no indication that a housing authority could not protect other tenants adequately by excluding applicants who had a history of the type of conduct which would interfere with their neighbors' rights. Such a standard could, of course, be applied on an equal basis to families containing illegitimates.

The director of the Little Rock Housing Authority, however, had a moral rather than a physical threat in mind when he asserted that the illegitimacy exclusion was intended to prevent the projects from becoming "hotbeds of delinquency." The authority claimed that promiscuity, and even prostitution, in its buildings had created such an unsavory atmosphere that "respectable" families were reluctant to live there. ${ }^{211}$ But assuming that threats of prostitution and promiscuity to the point of nuisance would be proper grounds for exclusion, the presence of illegitimate children should not be used as evidence of such a threat. Their status creates at most an inexact inference of prostitution

207 See Gilhool, Joseph \& Stein, Social Science Data Relating to Policy Excluding Unwed Mothers from Public Housing, October 20, 1968 (mimeograph, Community Legal Services, Inc., Philadelphia); C. VINCENT, UnMarRIEd Mothers 53-123 (1961). 208 See M. R. Wright, 80 Unmarried Mothers Who Kept Therr Babies (Calif. Dept. of Social Welfare, 1965); Berg, Utilizing the Strengths of Unwed Mothers in the AFDC Program, 43 CHILD WeLFaRe 333, 337-39 (1964).

$209 I d$. 1967).

210 But see Thomas v. Housing Authority, 282 F. Supp. 575, 581 (E.D. Ark. 211282 F. Supp. at 578-80. 
or overt promiscuity. Since a housing authority has the alternative of relying on direct evidence of such conduct, it ought not to use a suspect classification as indirect evidence.

A somewhat more subtle argument is that the very presence of illegitimate children in a family creates a moral threat by example to other tenants. But this "moral leper" theory violates the recent HUD circular mentioned above. ${ }^{212}$ The circular provides, inter alia, that an authority may establish criteria for admission and eviction

bearing on whether the conduct of . . . tenants . . . does or would be likely to interfere with other tenants in such a manner as to materially diminish their enjoyment of the premises. Such interference must relate to the actual or threatened conduct of the tenant and not be based solely on such matters as the marital status of the family, the legitimacy of the children in the family, police records, etc. ${ }^{213}$

This requirement reinforces the conclusion that here, too, the authority ought not to be constitutionally allowed to use a suspect classification when other means of determination are available.

The eviction of public housing tenants, when a member of the family gives birth to an illegitimate child, presents a somewhat different problem from the refusal to admit a family which already includes such a child. The assertion that the exclusion deters potential illegitimate parents is more likely to be accurate. While the extent to which any sanction actually deters illegitimacy is uncertain, eviction is so serious a penalty that it is probably as effective a deterrent as the criminal law..$^{214}$ But even if the deterrence is effective and even if government can constitutionally regulate the private non-violent sexual conduct of consenting adults, there remains the question whether housing authorities are the proper bodies to promote the policy of general deterrence. The HUD circular indicates that the department has concluded that they are not. The circular would allow eviction only for conduct interfering with other tenants. ${ }^{215}$ The same result might be reached under the equal protection clause on the ground that general deterrence is not related to the purposes of the housing act. ${ }^{216}$ Although the act does contemplate that the housing program would promote morality, this

212 Note 205 supra \& accompanying text.

213 Id.

214 Traditional criminal sanctions against fornication and bastardy have themselves been ineffective, at least in part because they have not been enforced. See Slovenko, Sex Mores and the Enforcement of the Law on Sex Crimes: A Study of the Status Quo, 15 Kan. L. Rev. 265 (1967) ; Ploscowe, Sex Offenses: The American Legal Context, 25 Law \& Contemp. Prob. 217, 218-19 (1960).

215 Circular, supra note 205.

21642 U.S.C. $\$ \$ 1401-36$ (1964). 
promotion is to result from an improvement in living conditions rather than from the creation of an agency to review the sexual behavior of public tenants. ${ }^{217}$

This view is supported by Chicago Housing Authority v. Blackwell, ${ }^{218}$ where the Supreme Court of Illinois held that a state provision granting the housing authority power to do what was "necessary" to secure federal assistance, did not authorize the authority to require a loyalty oath as a condition to eligibility for low-cost housing. ${ }^{219}$ The state housing authority argued that the loyalty oath requirement was pursuant to the "Gwinn Amendment" ${ }^{220}$ to the Federal Housing Act and was authorized by state law since, in light of the amendment, the oath would help secure federal funds. The court declared that the purpose of the state housing law was to eradicate slums and to provide lowincome housing and that the exclusion of otherwise qualified applicants solely because of membership in a subversive organization did not further this purpose. Thus it interpreted the state law as not authorizing the loyalty oath requirement despite the "Gwinn Amendment." 221 Similarly, the deterrence of sexual "sin" is no more related to the purpose of public housing than deterrence of subversive activity.

\section{E. Custody and Visitation}

\section{The Mother}

A mother normally has the right to custody of her illegitimate children subject to the same degree of supervision which the courts exercise over the mothers of legitimate children. ${ }^{222}$ This right derives from the widely recognized common law presumption that maternal custody is in the best interests of a child. ${ }^{223}$ It is therefore clear that the child as well as the mother has a presumptive right to maternal custody. A recent custody case, however, illustrates the kind of penalties which zealous state officials sometimes try to inflict on illegitimates. A Maryland statute provides that children may be taken from their mother when they are neglected ${ }^{224}$ - a condition which is defined to include the existence of an "unstable moral environment." In In re

21742 U.S.C. $\$ 1401$ (1964).

2184 IIl. 2d 319, 122 N.E.2d 522 (1954).

$219 \mathrm{Id}$. at 326,122 N.E.2d at 526.

220 The "Gwinn Amendment," adopted as a rider to the Independent Offices Appropriation Act of 1952, 66 Stat. 393, 403 (1952), provides

no housing unit constructed under the United States Housing Act of 1937, as

amended, shall be occupied by a person who is a member of an organization designated as subversive by the Attorney General.

2214 I1l. $2 \mathrm{~d}$ at 326,122 N.E.2d at 526.

222 See Annot., 98 A.L.R.2d 417, 420 (1964).

223 Id. at 427-34.

224 MD. ANn. Code art. 26, §52 (1967). 
Cager, ${ }^{225}$ a lower Maryland court held that the birth to a mother of a second illegitimate child was in itself sufficient evidence of an unstable moral environment to constitute neglect.

Most first illegitimate children $* * *$ The court there stated: are the result of a mistake $* * *$. The second time around we think represents a lack of judgment and demonstrates an unstable moral attitude on the part of the mother $* * *$ that is inconsistent with the minimum moral standard the community requires. ${ }^{226}$

The Maryland Court of Appeals reversed, holding that the lower court's test for neglect was not "reasonably or fairly implicit in the statute." ${ }^{227}$ The court said:

The best interest of a child may or may not be served by removing it from the custody of a mother who has had another illegitimate child but the sole test, automatically applied, cannot in fact or law be pregnancy with an illegitimate child or the recent birth of an illegitimate child added to the presence of an existing illegitimate offspring. Cf. Levy v. Louisiana, 391 U.S. 68 ....228

The Maryland court relied on statutory grounds, but it apparently interpreted Levy expansively to call into question the use of illegitimacy as a classification when, although having some relationship to a legitimate legislative purpose, it imprecisely identifies the group the state intends to reach. The court also invoked due process principles to reinforce its statutory holding; it saw the case as having been

instituted not to serve and perpetuate the best interests of the children but rather impermissibly to use the children as pawns in a plan to punish their mothers for their past promiscuity and to discourage them and other females of like weaknesses and inclinations from future productivity. ${ }^{229}$

If the lower court in Cager had merely given some weight to the presence of more than one illegitimate child in a household, a more

225251 Md. 473, 248 A.2d 384 (1968).

$226 \mathrm{Id}$. at $478,248 \mathrm{A.2d}$ at 387 , quoting the circuit court. By stipulation, the presence of 2 or more illegitimate children in the families of the allegedly neglected children was the only evidence of neglect before the court. This unusual agreement occurred because Cager was brought as a test case by the local state attorney in an apparent campaign to discourage promiscuity and illegitimacy. Id. at 481, 248 A.2d at 389. The attorney had obtained the information about the families from the welfare department. The Maryland Court of Appeals relied on this violation of state and federal statutes on the confidentiality of welfare records as an alternate ground for reversal. Id. at 481,248 A.2d at 389 .

227 Id. at 479,248 A.2d at 388.

228 Id. at 480,248 A.2d at 388.

229 Id. at 480,248 A. 2 d. at 389 . 
difficult question would have been raised: does state regulation of the moral atmosphere created by a mother's consensual sexual conduct violate either her right to privacy in sexual matters ${ }^{230}$ or her right to raise her children in accordance with her unconventional views? ${ }^{231}$

\section{The Father}

At common law, a father never had the right to custody of his illegitimate child, ${ }^{232}$ but in a number of states this absolute rule has been altered by statute and judicial decision. In many states, a father is now able to obtain custody after the death of the mother. ${ }^{233}$ The question of paternal custody also arises when a mother decides to relinquish the child. Usually the father's consent to such relinquishment is not required, as it would be with respect to a legitimate child unless the father had been adjudicated unfit. ${ }^{234}$ Some states even exclude the father from any participation in the resulting custody hearing. ${ }^{235}$

There seems to be no proper reason for this exclusion. The restriction has no significant deterrent value, and a court would obviously be under no obligation to accept the suggestions of a father it considered unreliable. If a father desires custody of the child either when the mother relinquishes it or when she dies, the more complex question arises: whether he should have the same presumptive right to custody which is accorded a legitimate father. ${ }^{236}$ In the absence of justification for the denial of such a right, a similar presumption should be accorded an illegitimate father since the act of stepping forward is prima facie evidence of the father's devotion to the child's welfare. It may be argued that an illegitimate child living with his father would be particularly susceptible to suffering because of his status. In fact, the opposite is probably true. In at least one state, an illegitimate child who lives with his father is automatically legitimated. ${ }^{237}$ Even where such a statute does not exist, the child probably has a greater opportunity of gaining legitimate status living with his father.

Additional considerations enter where the illegitimate father also has a legitimate family. ${ }^{238}$ The influence and interests of the legitimate

230 Text accompanying notes 95-104 supra.

231 Cf. Pierce v. Society of Sisters, 268 U.S. 510 (1925); Meyer v. Nebraska, 262 U.S. 390 (1923).

232 See Note, Father of An Illegitinate Child-His Right to Be Heard, 50

MINN. L. REv. 1071, 1072 (1966).

233 Id. $1073-74$.

$234 I d$. $1075-76$.

$235 I d .1076$ n.29.

236 See Boone v. Wyman, 295 F. Supp. 1143 (S.D.N.Y. 1969), appeal docketed,

No. 33243, 2d Cir., Feb. 6, 1969.

237 See CaL. Crv. Code $\$ 230$ (West 1954).

238 Cf. Krause, supra note 118, at 503. 
wife and children could certainly be considered in a custody hearing. Unless the illegitimate child is adulterous, however, the problems are really no different from those presented when a divorced and remarried man desires custody of his legitimate children by his first wife. Thus, aside from the special problem of the adulterous child, denial to the illegitimate father of a presumptive right to custody lacks a rational relation to the object of custody provisions. This result would not prevent a court from refusing custody to an illegitimate father it found unfit, since a legitimate father could be refused on a similar basis.

A related issue is the right of a father to visit his illegitimate child while the child is in his mother's custody. Most states allow visitation depending on the situation of the particular child, whether or not illegitimacy is involved, ${ }^{239}$ and a number of cases have specifically given illegitimate fathers the right to visit. ${ }^{240}$ In Wallace $v$. Wallace, ${ }^{241}$ however, the Supreme Court of Illinois stated that the Illinois paternity act established a conclusive presumption that an illegitimate father had absolutely no visitation rights and by logical implication ruled that this was in the best interests of the child. ${ }^{242}$ While there may often be special reasons for denying visitation rights to an illegitimate father, the unrebuttable presumption created in Wallace is imprecise because an opportunity to see his father might sometimes be a clear benefit to the child. Although visitation is usually a matter left to a court's largely unreviewable discretion, the rationale of Glona would support the right of a father of an illegitimate child to appeal to judicial discretion, even though the exercise of this discretion will often deny him the right to visit.

A recent case has raised the issue, in an unusual context, of a father's right to visit his illegitimate child. A county welfare board interpreted federal and state statutes conditioning eligibility for the Aid for Dependent Children (AFDC) Program on the "continuing absence" of a parent. The effect of this requirement was to deny benefits to illegitimate children visited by their fathers, but not to legitimate children visited by divorced or separated fathers. In Jones v. Welfare Board, ${ }^{243}$ the mother of two illegitimate children has sued

239 Note, $A$ Father's Right to Visit His Illegitimate Child, 27 Oнто Sr. L.J. 738, 739 (1966).

240 Id. 739-40. See, e.g., Commonwealth v. Rozanski, 206 Pa. Super. 397, 213 A.2d 155 (1965).

24160 Ill. App. 2d 300, 210 N.E.2d 4 (1965).

242 The court's holding was concerned with a procedural aspect of the case. It denied the child any common law basis to sue for his father's companionship. However, the court made it quite clear that an illegitimate father had no right to the custody or society of his child.

243 No. 4-68 Civ. 248 (D. Minn., filed July 30, 1968) (temporary restraining order). 
on behalf of herself, her children, and others simliarly situated to enjoin the enforcement of the welfare board's policy on the grounds that it violates equal protection, due process, and the right to privacy. The federal district court in Minnesota has granted a temporary restraining order against termination of AFDC benefits to the named plaintiffs. ${ }^{244}$ The purpose of the denial of aid is apparently to regulate the sexual activities of welfare mothers by denying access to likely sex partners. This regulation should be illegal under King $v$. Smith. ${ }^{245}$ There the Supreme Court held that Alabama's "substitute father" rule denying aid to families in which the mother was having sexual relations violated the Social Security Act. ${ }^{246}$ Even if legal under the Act, this policy cannot justify the burden on illegitimate fathers and children under Levy and Glona. The rule is imprecise because it unnecessarily excludes consideration of factors relevant to deciding whether there is a danger of illicit sex: for example, the actual relationship between the parents, the age of the children, and the place of visitation.

\section{F. Name}

A less tangible form of discrimination which illegitimate children now suffer is the denial of a right to use their father's name. ${ }^{247}$ Although most illegitimates live with their mothers and might prefer to use her name, some do not and may prefer their father's name. Although the effects of this deprivation are uncertain, the disadvantage seems unjustifiable under Levy. It has been suggested that the denial to illegitimates of this right is reasonable because a family name serves the function of identifying an individual with a "nuclear" family group, ${ }^{248}$ and a father's illegitimate child will not usually be a member of this group. But identification of the "nuclear" family is probably not the purpose of names, since they are commonly shared by a much larger group of relatives, and since legitimate children, not living with their fathers, are not disqualified from using his name. If anything, a name seems to identify a group bound by certain legal relationships. Since the discriminations against illegitimates with respect to other legal relationships are now invalid under Levy and Glona, there is no longer any justification for discrimination with respect to name, assuming, of course, that paternity has been established.

244. $I d$.

245392 U.S. 309 (1968).

246 Id. at 327. See also note 171 supra.

247 See Krause, note 118 supra, at 503.

$248 I d$. 


\section{CoNCLUSION}

Because the Levy and Glona decisions dealt summarily with a particularly unreasonable statute, they did not consider all the possible justifications for classifications based on illegitimacy. The Court did, however, establish that a state will carry a heavy burden in attempting to show a reasonable relationship between a classification based on illegitimacy and a legitimate state purpose. ${ }^{249}$ It is also important that in Glona the Court considered and rejected the claims that an illegitimate parent's problem of proving relationship justified a denial of substantive rights ${ }^{250}$ and that the policy of deterrence justified a discrimination against illegitimate parents. ${ }^{251}$ Thus, while the Court wrote cryptically, its opinions indicate that no major discriminations against illegitimates should survive.

In the cases involving discrimination against illegitimates decided since Levy, the courts, like the Supreme Court itself, have failed to discuss all the problems involved. Most have accurately, but inadequately, treated the discriminations as the vestiges of earlier social customs. Although the new attitudes of these courts are a welcome change, the refusal of at least one court to extend the principles of Levy to the paternal relationship indicates that a more thorough analysis of the issues will be necessary before illegitimates are everywhere guaranteed the "correlative rights which other citizens enjoy." 252

249391 U.S. at 71-72.

250391 U.S. at 76.

251 Id. at 75.

252391 U.S. at 71. 